\title{
The influence of weather conditions on annual height increments of Scots pine
}

\author{
Katarzyna Kaźmierczak ${ }^{1}$, Bogna Zawieja ${ }^{2}$ \\ ${ }^{1}$ Department of Forest Management, Poznań University of Life Sciences, Wojska Polskiego 28, \\ 60-637 Poznań, Poland, kasiakdendro@wp.pl \\ ${ }^{2}$ Department of Mathematical and Statistical Methods, Poznań University of Life Sciences, \\ Wojska Polskiego 28, 60-637 Poznań, Poland, bogna13@up.poznan.pl
}

\section{SUMMARY}

\begin{abstract}
Annual height increments are a very important characteristic of Scots pine. They have a direct effect on the determination of the dendrometric properties of a stand, such as volume increment. In the present study the data concern height increments of the main shoot in selected age classes of trees (age 72 to 92 years). A relationship is determined between the values of the increments and meteorological conditions such as temperature, precipitation and sunshine. On the basis of lasso regression analysis, precipitation in the year preceding the incremental season was shown to have the greatest effect on height increments of Scots pine.
\end{abstract}

Key words: height increments, lasso regression, precipitation, Scots pine (Pinus sylvestris $\mathrm{L}$.), sunshine, temperature.

\section{Introduction}

The annual height increment of trees is regarded as a major dendrometric characteristic, since it has a direct influence on the accuracy of determination of tree and stand volume increments. Knowledge of this increment is essential for methods used to determine stand productivity (Bruchwald, 1973). It is a variable characteristic and depends on several factors (Kaźmierczak, 2004, 2005, Najgrakowski, 1998). The most important of these factors include the tree species, its age, social class of the tree's position in the stand, and soil, climatic and meteorological conditions. Direct evaluation of height increments in 
standing trees is quite difficult, and sometimes impossible. The general regularity of the growing process is independent of the tree species. Differences are connected with the magnitude and length of natural phases. In the first years of tree life, i.e. the youth or juvenile phase, the increment in height is not large. The next period is called the height season strength phase or the vigor phase. In this period trees exhibit their largest annual height increments, and the culmination point occurs - the year with the greatest height increment. The duration of this period depends mainly on the tree species and climatic conditions. After several years of such increments there comes the senile phase - a period of stabilized increments, much smaller or occasionally identical to those of the second phase (Beker, 1998).

In Poland the vegetation period of Scots pine extends from May to September. After the vegetation season the increments lignify, and their length does not change in the next seasons. As mentioned above, the length of the annual shoots depends on the weather during growth (in the vegetation year) as well as in the previous year. In the period of July-September of the preceding year buds are formed and reserve substances are accumulated, which in large part will be used for the height increment in the next year (Assmann, 1968). Scots pine grows in areas in which temperatures range from $-60^{\circ} \mathrm{C}$ to $+40^{\circ} \mathrm{C}$. In Poland, pines tolerate annual precipitation ranging from 200 to $1000 \mathrm{~mm}$, as has been shown by Jasnowska (1977) and Wilczyński (1999). The species belongs to the northern tree type (boreal-arctic northern) and the mountain tree type.

The present work considers the relationship between weather conditions and the height increments of Scots pine. Three age groups are analyzed: 72, 84 and 92 years, all within the senile phase of growth. The height increments of the analyzed trees are not so great, but depend on weather conditions to a greater extent than those of younger trees. The height increments depend not only on the weather in the incremental season, but also on the weather at the time of the formation of buds. In this study, quarterly averages are used. To determine which of the aspects of weather conditions (temperature, precipitation and 
sunshine) and which period (quarter) of the year have the greatest impact on the analyzed characteristic, the lasso regression method was used.

\section{Data}

The analyzed Scots pine stands are located in the Zielonka Experimental Forest District. They grow in fresh mixed coniferous forests. The sample trees were selected following the methodology developed by Draudt (Grochowski, 1973). There were 25 trees selected separately from three age classes. For each selected tree, the length of current annual increments was measured (based on branch whorls). The height increments were measured over a ten-year vegetation period (from 1989 to 1998). Consequently the experimental material contained ten years of measurements of 75 Scots pine stems. Attention is focused here on the old trees, aged 72, 84 and 92 years, because the height increments of these trees (being in the senile phase) are not so great, but they depend on the weather conditions. The weather data were obtained at the Meteorological Station in Zielonka. Temperature was measured at a height of 2 $\mathrm{m}$. Temperature is given in degrees Celsius, precipitation in millimeters, and sunshine in hours. In previous work (for example Kazimierczak and Zawieja,, 2011) the influence of monthly meteorological conditions on height increments has been considered. The present work considers the impact of quarters of the year on height increments. The quarterly averages of all factors are used, the periods considered being the third and fourth quarters of the year preceding the vegetation season, and the first, second and third quarters of the year of the vegetation season. Quarterly averages of the three above-mentioned weather factors are plotted in Figure 1, where the maximum and minimum for each quarter are also marked. 


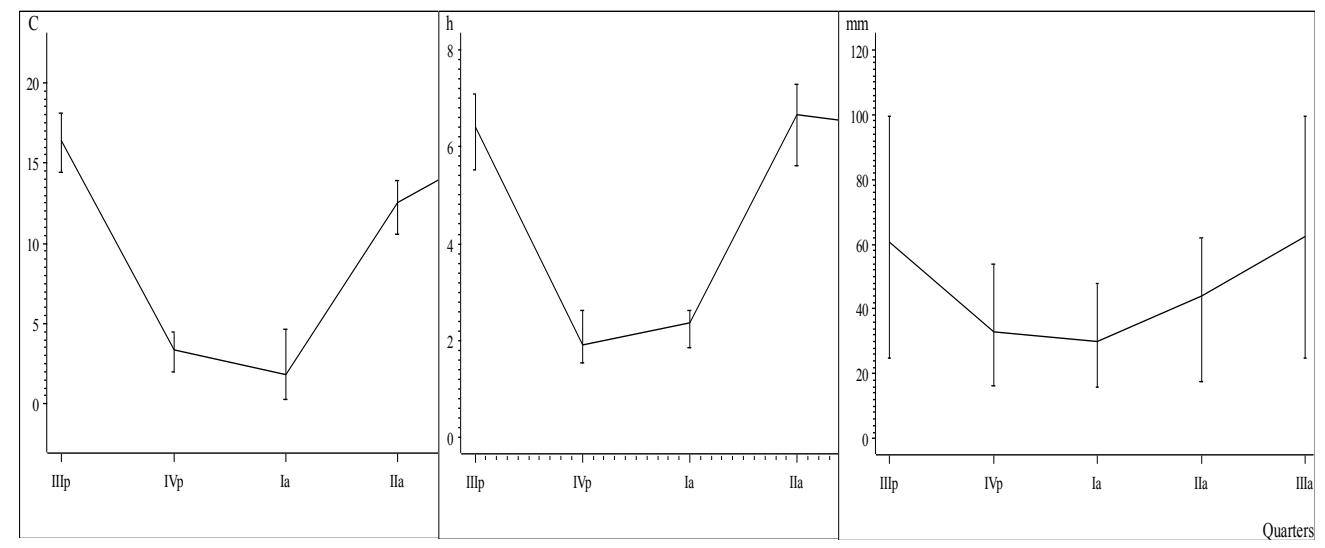

Figure 1. Mean, maximum and minimum values for temperature, sunshine and total precipitation per quarter prior to the vegetation season (IIIp, IVp) and during the vegetation season (Ia, IIa, IIIa)

\section{Method}

The relationship between height increments and various weather factors (temperature, precipitation, sunshine) is most frequently determined using correlation coefficients (for example Cedro, 2001), but it is more correct to use the regression method for this purpose. In the case where the number of explanatory variables is large and they are close to collinearity, bridge regression should be used.

Let $\mathbf{y}=\mathbf{X} \boldsymbol{\beta}+\boldsymbol{\varepsilon}$, where $\mathbf{y}$ is an $n$-dimensional vector of random responses, $\mathbf{X}$ an $n \times p$ design matrix, $\boldsymbol{\beta}$ a $p$-dimensional vector of parameters, and $\boldsymbol{\varepsilon}$ an $n$-dimensional vector of i.i.d. random errors. In this model the unbiased estimator $\boldsymbol{\beta}$ is given by $\boldsymbol{\beta}=\left(\mathbf{X}^{\prime} \mathbf{X}\right)^{-1} \mathbf{X}^{\prime} \mathbf{y}$, which was obtained using the ordinary least squares method $R S S=(\mathbf{y}-\mathbf{X} \boldsymbol{\beta})^{\prime}(\mathbf{y}-\mathbf{X} \boldsymbol{\beta})$. If the covariance matrix is close to singular by collinearity of explanatory variables, then $R S S$ minimization is performed with the constraint $\Sigma\left|\beta_{j}\right|^{k} \leq t$, where $k=0,1,2, \ldots, t \geq 0$, and then the biased estimator is obtained by minimizing the expression $\min _{\boldsymbol{\beta}}\left(R S S+\lambda \sum_{j}\left|\beta_{j}\right|^{k}\right)$, where $\lambda=\lambda(t) \geq 0$ is a function $t$. If $k=1$, this is called lasso regression; if $k=2$, it is called ridge regression. The 
bridge estimator takes the form $\boldsymbol{\beta}_{b r}=\left[\mathbf{X}^{\prime} \mathbf{X}+2^{-1} \lambda k \operatorname{diag}\left(\left|\beta_{j}\right|^{k-2}\right)\right]^{-1} \mathbf{X}^{\prime} \mathbf{y}$. Let $\mathbf{b}_{b r}$ be the estimator of $\boldsymbol{\beta}_{b r}$ from a sample. In practice the series of values of $\mathbf{b}_{b r}$ are detected using different values of the parameter $\lambda(\lambda \in[0 ; 1])$, and $\lambda$ is then chosen such that $\boldsymbol{\beta}_{b r}$ stabilizes.

For the data considered here, the matrix $\mathbf{X}^{\prime} \mathbf{X}$ is close to singular. Therefore the relationship between weather conditions and increments of Scots pine was detected using the lasso regression method with the Schwarz Bayesian information criterion as a method for the choice of exploratory variables.

\section{Results}

In earlier studies concerning dependencies between tree increments, temperature and precipitation (Kaźmierczak and Zawieja, 2011) these relationships have frequently been found to be quadratic rather than linear. Thus regression equations were formulated taking into consideration all investigated factors to the first and second powers (with all quarterly mean temperatures, precipitation and sunshine considered). As a result, as many as 30 factors (independent variables) were investigated jointly in each age class, and so it was necessary to use bridge regression. Independent variables were selected applying the lasso method; hence in the choose and stop steps of the sequential procedure the BIC criterion was used. The following equations were obtained: for 72-year trees:

$$
y_{72}=23.0759+0.0602 o_{I I p}-0.2394 o_{I V p} \quad \mathrm{BIC}=1022.82
$$

for 84-year trees:

$$
y_{84}=18.1823+0.0032 o_{I I I p}-0.0032 o_{I V p}^{2} \quad \mathrm{BIC}=965.25
$$

for 92-year trees:

$$
y_{92}=11.1550+0.0587 o_{I I I p}-0.0024 o_{I V p}^{2} \quad \mathrm{BIC}=852.62
$$

where $o_{\mathrm{III} p}$ and $o_{\mathrm{IV} p}$ denote the total precipitation in the third and fourth quarters of the year preceding the vegetation season. 
For all of the investigated age classes, the factor representing precipitation in the third and fourth quarters of the year preceding the vegetation year was selected. Thus it may be concluded that among the weather factors, the greatest effect on annual increments of height in trees aged more than 60 years (the first measurement was made on 62-year-old trees) is observed to come from precipitation in the months from July to December in the year preceding those increments. Precipitation in the third quarter has a positive effect on increments in the following year, while abundant precipitation in the months from October to December has a negative effect on those increments.

\section{Discussion}

There are no significant references in the literature to the impact of weather conditions on the annual height increment. Previous research has mainly related to the impact of weather features on the radial increment. Many scientists have dealt with the effect of atmospheric conditions on the increment in the diameter of trees (radial growth). Zienkiewicz (1946) and Ermich (1953) were the first to undertake such studies in Poland. Later the influence of climatic conditions on radial growth of trees growing in peat soils was described by Jasnowska (1977) and Zielski (1996). Cedro (2001) conducted similar investigations covering the period 1949-1998 in north-western Poland. In a study by Cedro (2001) the author investigated the effect of temperature and precipitation on increments in the diameter of Scots pine. She found that a high temperature in September had a negative effect on those increments. It was also reported that the variation (ranges) of temperature throughout the year had an effect on the increments. In a paper by Kaźmierczak and Zawieja (2008) a significant correlation between height increments and diameter increments was shown.

A strong relationship between mean temperature in June and August in the preceding year and the length of the apical shoot in 20-year-old pines was shown by Junttila and Heide (1981). Michalak (1977) investigated the pattern of diurnal height increments in a three-year period depending on variable 
meteorological conditions in the vegetation season in pine, fir, spruce, larch, oak and beech. In a paper by Zielski (1996) a significant correlation between temperature and diameter increments of pine in February and March was established. The results obtained by Feliksik (1988) for pine trees from forest areas in Dąbrowa Tarnowska are similar, namely that increments in the width of the wood were strongly dependent on temperature (from January to March). Oleksyn et al. (1993) concluded that there is a significant relationship between radial growth and winter temperatures. The formation of wide annual rings is favored by warm, short winters and wet, warm summers, while frosty, long winters and dry, hot summers cause a reduction in increments, as reported by Wilczyński (2004).

Dependences of increments on weather conditions were analyzed by Kaźmierczak and Zawieja (2011) for one age group (24-year) of pine stands, taking account of the mean annual temperature and precipitation in the vegetation period. The insolation factor is rarely considered in the literature.

One of the few papers concerning the effect of insolation on increments in the tree ring width of Alnus japonica is that of Haraguchi et al. (1999). A significant positive correlation was found between tree ring width indices and corresponding annual mean temperatures, and with both mean temperature and cumulative sunshine time during the growing season (June-October). Precipitation during the period with generally the lowest redox potential (September) showed a significant positive correlation with tree growth. June sunshine in the ring formation year and August sunshine during the previous growth year also showed significant positive correlations. Wilczyński and Podlaski (2007) considered the same problem in relation to cucumbertree and black alder.

A tree ring width chronology of Mongolian pine (Pinus sylvestris var. mongolica) in China was developed by Shi et al. (2012). The relationships between ring width and climatic factors were evaluated using correlation and response function analyses. Radial growth of Mongolian pine on sandy soils was negatively correlated with the average monthly temperature and monthly 
maximum temperature, with significant negative correlations in April and in the growing season (June-September). Tree ring width was significantly positively correlated with monthly precipitation during May-August. The growth of Mongolian pine in the Hulunbuir Sand Land is limited by both temperature and precipitation, but the influence of temperature on tree ring growth is less than the influence of precipitation. The relationship between radial growth and climate factors can be described as precipitation-sensitive.

\section{Conclusions}

Significant correlations between precipitation values and height increments in Scots pine have been shown, and the particular effect of one of the weather factors in the year preceding the vegetation season has been demonstrated. In the paper by Kaźmierczak and Zawieja (2011) the relationships were considered separately for dependence between temperature and height increments and between precipitation and height increments, and in that case too the greatest influence on those increments was found to come from the weather conditions in the year preceding the vegetation season. In the present study the two factors were considered jointly, and the precipitation values for the third and fourth quarters of the year preceding the vegetation season were shown to be more influential.

\section{REFERENCES}

Assmann E. (1968): Nauka o produkcyjności lasu [Forest productivity science]. PWRiL, Warszawa.

Beker C. (1998): Przyrost wysokości w drzewostanach sosnowych starszych klas wieku [Height increment in pine stands of older age classes]. Sylwan 8: 43-54.

Bruchwald A. (1973): Ocena przydatności dla praktyki gospodarczej sposobów określania miąższości drzewostanu [Evaluation of usefulness for economic practice of methods of determination of stand volume]. ZN SGGW, Rozprawy Naukowe 25.

Cedro A. (2001): Dependence of radial growth of Pinus Sylvestris L. from western Pomerania on the rainfall and temperature conditions. Geochronometria 20: 69-74.

Ermich K. (1953): Wpływ czynników klimatycznych na przyrost dębu szypułkowego i sosny zwyczajnej. Próba analizy zagadnienia [The influence of climatic conditions 
The influence of weather conditions on annual height increments of Scots pine 151

on Quercus robur and Pinus sylvestris growth]. Prace Rolniczo-Leśne PAU 68: $1-61$.

Feliksik E. (1988): Badania wpływu klimatu na szerokość przyrostów rocznych drewna sosny pospolitej [Investigation of the effect of climate on the width of annual rings of Scots pine wood]. Z. N. ATR im. Śniadeckich w Bydgoszczy nr 158, Rolnictwo 27: $11-17$.

Grochowski J. (1973): Dendrometria [Forest mensuration]. PWRiL, Warszawa.

Haraguchi A., Shibasaki M., Noda M., Tomizawa H., Nishio F. (1999): Climatic factors influencing the tree-ring growth of Alnus japonica in Kiritapp Mire, Northern Japan. Wetlands 19: 100-105.

Jasnowska J. (1977): Czynniki wpływające na rozmiary słojów rocznych drewna sosny na torfowisku wysokim w zespole Vaccinio uliginosi-pinetum [Influence of some factors on width of annual rings of pine growing on a peat bog in Vaccino uliginosipinetum plants]. Rocznik Dendrologiczny XXX: 5-33.

Junttila O., Heide O.M. (1981): Shoot and needle growth in Pinus sylvestris as related to temperature in northern Fennoscandia. For. Sci. 27, 423-430.

Kaźmierczak K. (2004): Dokładność wybranych sposobów określania okresowego przyrostu wysokości drzew [The accuracy of chosen methods of tree height increment calculation]. Roczniki AR Poznań CCCLXIV: 67-78.

Kaźmierczak K. (2005): Przyrost wysokości i dokładność różnych metod jego określania na przykładzie wybranych drzewostanów sosnowych [The height increment and accuracy of different methods of its calculation in selected Scots pine stands]. Rozprawy Naukowe vol. 362, Roczniki AR Poznań.

Kaźmierczak K., Zawieja B. (2008): An attempt to assess the dependence of 5-year increment in height in 24-year old pines on selected traits. XVIII Summer School of Biometrics, Biometrical Methods and Models in Agricultural Science, Research and Education: 183-190.

Kaźmierczak K., Zawieja B. (2011): Dependence of height increment on the precipitations and temperature conditions in a 24-year pine stand. Colloquium Biometricum 41: 229-240 .

Michalak K. (1977): Rytmika przyrostu wysokości w okresie wegetacji ważniejszych gatunków drzew leśnych i jej zależność od elementów meteorologicznych [The rhythm of increment in height during vegetation of major forest tree species and its dependence on meteorological elements]. ZN SGGW, Leśnictwo 25: 19-44.

Najgrakowski T. (1998): Dendrometryczna charakterystyka wybranych drzewostanów sosnowych na terenach objętych w latach 1978-1983 gradacją brudnicy mniszki [Dendrometric characteristics of selected pine stands under the influence of Lymantria monacha gradation]. Maszyn. Kat. Dendrom. AR, Poznań.

Oleksyn J., Fritts H.C., Hughes M.K. (1993): Tree-ring analysis of different Pinus sylvestris provenans, Quercus robur, Larix deciduas and L. deciduas x L. kaempferi affected by air pollution. Arboretum Kórnickie 38: 87-111.

Shi Z., Gao J., Yang X., Jia Z., Shang J., Feng Ch., Lü S. (2012): Response of Mongolian pine radial growth to climate in Hulunbuir Sand Land, Inner Mongolia, China. Journal of Food, Agriculture and Environment 10(2): 884-890.

Wilczyński S. (1999): Dendroklimatologia sosny zwyczajnej (Pinus sylvestris L.) z wybranych stanowisk w Polsce. [Dendroclimatology of Pinus silvestris L. from 
some sites in Poland. PhD Thesis]. Rozprawa doktorska wykonana w Zakładzie Klimatologii Leśnej AR w Krakowie.

Wilczyński S. (2004): Lata „wskaźnikowe” i „wyjątkowe” w ocenie związków „przyrost radialny-klimat" [The pointer and exceptional years in assessment of relationships between radial growth and climate]. Sylwan 5: 30-40.

Wilczyński S., Podlaski R. (2007): Air temperature, precipitation, and sunshine - the factors deciding on the activity of cucumbertree (Magnolia acuminata L.) vascular cambium. EJPAU 10(1).

Zielski A. (1996): Wpływ temperatury i opadów na szerokość słojów rocznych drewna $\mathrm{u}$ sosny zwyczajnej (Pinus sylvestris L.) w rejonie Torunia [The influence of temperature and precipitation on width of annual rings of pine (Pinus sylvestris L.)]. Sylwan 2: 71-79.

Zienkiewicz W. (1946): Badania nad wartością rocznego przyrostu drzew dla studiów wahań klimatycznych [Investigations on annual growth of trees for studies of climatic changes]. Annales UMS 1: 177-234. 